\title{
LATIHAN OTOT DASAR PANGGUL DAN KOMUNIKASI SEKSUAL PADA IBU PASCASALIN
}

\author{
Novita Dewi Pramanik ${ }^{1}$, Tita Husnitawati Madjid ${ }^{2}$, Herman Susanto ${ }^{3}$, Herry Herman ${ }^{4}$, \\ Indun Lestari Setyono ${ }^{5}$, Fedri Ruluwedrata Rinawan ${ }^{6}$ \\ ${ }^{1}$ Politeknik Kesehatan Kemenkes Bandung, Jl. Dr. Sumeru No. 116 Bogor 16111, \\ ${ }^{2,3}$ Departemen Obstetri dan Ginekologi, Fakultas Kedokteran Universitas Padjadjaran \\ ${ }^{4}$ Departemen Orthopedi dan traumatologi, Fakultas Kedokteran Universitas Padjadjaran \\ ${ }^{5}$ Departemen Psikologi, Fakultas Psikologi Universitas Padjadjaran \\ ${ }^{6}$ Departemen Ilmu Kesehatan Masyarakat, Fakultas Kedokteran Universitas Padjadjaran \\ pramaniknovita@gmail.com
}

\section{(Pelvic Floor Muscle Exercise And Sexual Communication On Postpartum Woman)}

\begin{abstract}
This study aimed was to discover the effect of combination of Pelvic Floor Muscle Exercise (PFME) and sexual communication on improving postpartum sexual intercourse quality. Respondents was woman who's in the range of 2-3 months postpartum. Research design uses concurrent embedded mixed methods. Quantitative phase using quasi-experimental pre-posttest control group design, while qualitative phase uses a phenomenological approach with in-depth interview techniques that seek information about the influence of PFME and sexual communication on postpartum sexual satisfaction. The Female Sexual Function Index (FSFI) questionnaire was used to measure 6 sexual dimensions that describe the quality of a sexual intercourse, that is sexual desire, sexual arousal, lubrication, orgasm, sexual satisfaction and pain during intercourse. Quantitative and qualitative analysis results showed improvement in sexual intercourse quality on both intervention and control groups $(p<0.05)$. The results of in-depth interviews emphasize that psychological elements play an important role in improving the quality of postpartum maternal sexual intercourse, that facilitated through sexual communication interventions.
\end{abstract}

Keywords: postpartum sexual intercourse, sexual communication, pelvic floor muscle exercise

Abstrak: Penelitian ini bertujuan untuk mengetahui pengaruh kombinasi Latihan Otot Dasar Panggul (LODP) dan komunikasi seksual terhadap peningkatan kualitas hubungan seksual ibu pascasalin. Responden penelitian adalah wanita yang berada dalam rentang 2-3 bulan pascasalin. Desain penelitian menggunakan metode campuran concurrent embedded. Pada tahap kuantitatif menggunakan eksperimen semu pre-posttest control group design, sedangkan tahap kualitatif menggunakan pendekatan fenomenologi dengan teknik wawancara mendalam yang berusaha menggali informasi mengenai pengaruh LODP dan komunikasi seksual terhadap kepuasan seksual ibu pascasalin. Kuesioner Female Sexual Function Index (FSFI) digunakan untuk mengukur 6 dimensi seksual yang menggambarkan kualitas sebuah hubungan seksual, yaitu hasrat seksual, gairah seksual, lubrikasi, orgasme, kepuasan seksual dan nyeri saat berhubungan seksual. Hasil analisis secara kuantitatif dan kualitatif menunjukkan adanya peningkatan kualitas hubungan seksual pada ibu pascasalin pada kelompok intervensi dan kontrol $(\mathrm{p}<0.05)$. Hasil wawancara mendalam mempertegas bahwa unsur psikologis memegang peranan penting dalam membantu meningkatkan kualitas hubungan seksual ibu pascasalin, yang terfasilitasi melalui intervensi komunikasi seksual.

Kata kunci: Hubungan seksual ibu pascasalin, komunikasi seksual, latihan otot dasar panggul 


\section{PENDAHULUAN}

Seksualitas dalam hirarki kebutuhan manusia yang dikembangkan oleh Abraham Maslow berada dalam kelompok kebutuhan fisiologis, bersama dengan makan, minum ataupun kebutuhan akan udara. Umumnya jika hal-hal dasar ini belum terpenuhi, maka seorang individu belum memiliki motivasi untuk mencapai tingkat kebutuhan yang lebih tinggi hirarkinya. Hal ini bermakna bahwa seksualitas merupakan salah satu unsur yang penting untuk dipenuhi dalam rangka pemenuhan kebutuhan dasar manusia. (Thielke et al., 2012)

Bersinggungan dengan kehidupan wanita, seksualitas merupakan sebuah fenomena multidimensi yang dapat dipengaruhi oleh faktor-faktor kontekstual, terutama faktor psikologis seperti stres, perasaan wanita tersebut, dukungan emosional ataupun hal yang berkaitan dengan hal tersebut (seperti kenyamanan dengan pasangan, karakter dan persepsi pasangan, gambaran diri, empati). Fungsi seksual pascasalin dipengaruhi oleh banyak faktor karena adanya perubahan signifikan dalam hal fisik, hormonal, psikologis, sosial dan kultural seperti beberapa perubahan anatomis akibat trauma traktus genital ataupun disfungsi organ pelvis dasar, pengaruh hormonal yang dapat mengakibatkan penurunan jumlah zat lubrikan, amenorrhea akibat proses menyusui, kualitas hubungan dengan pasangan, kelelahan, adanya lokhia, dispareunia, rasa takut bahwa bayinya akan terbangun atau tidak mendengar bayinya terbangun, rasa takut akan sakit, dan kurangnya kepercayaan diri karena merasa tidak menarik lagi. Kesemua hal ini dapat memberikan dampak negatif pada kehidupan wanita seperti misalnya terjadi disfungsi seksual, hilangnya libido, tidak orgasme (anorgasmia), dan vaginismus. Kesehatan seksual pasangan juga dikhawatirkan akan terpengaruh jika hal seperti ini terjadi. (Acele \& Karaçam, 2012; Johnson, 2011;
Lamont et al., 2012; Serati et al., 2010; Zakšek, 2015)

Beberapa studi melaporkan sekitar 90\% wanita pascasalin melakukan hubungan seksual kembali dalam waktu 3 bulan pertama pascasalin dengan lebih dari $50 \%$ di antaranya mengalami morbiditas seksual seperti dispareunia (karena adanya peregangan perineum saat persalinan, laserasi, persalinan per vaginam dengan alat dan episiotomi), kekeringan vagina, anorgasmia, keketatan vagina, kelonggaran vagina, perdarahan atau iritasi pascakoitus, bahkan penurunan libido yang sering dialami sejak trimester akhir kehamilan mengalami peningkatan signifikan pada 3 bulan pertama masa pascasalin. Keluhankeluhan tidak dapat dianggap sepele karena pada umumnya dapat terselesaikan dalam waktu satu tahun pertama pascasalin. (Acele \& Karaçam, 2012; Citak et al., 2010; Lamont et al., 2012; Seehusen, Baird, \& Bode, 2014; Serati et al., 2010)

Latihan Otot Dasar Panggul (LODP) merupakan latihan penguatan isometrik terhadap otot-otot dasar panggul, terutama otot pubokoksigeal dengan tujuan agar dapat melawan penurunan organ panggul, dan mengembalikan hubungan anatomis antara organ-organ panggul seperti semula serta menjaga keseimbangan otot-otot abdominal, punggung dan kuadran bawah yang vital untuk program rehabilitasi. Banyak studi dilakukan dengan memberikan intervensi berupa LODP kepada wanita baik dalam keadaan pascasalin ataupun bukan, dan menghasilkan hal yang serupa yaitu adanya peningkatan fungsi seksual pada wanita tersebut. (Brækken, Majida, Ellström Engh, \& Bø, 2015; Citak et al., 2010; Galuh Suryondari \& Yuni Indah Nurmala, 2016)

Salah satu elemen terpenting untuk dibangun dalam menuju kehidupan seksual yang lebih baik adalah melakukan komunikasi seksual dengan pasangan. Hal ini terbukti memiliki korelasi positif terhadap kepuasan secara menyeluruh, 
baik kepuasan dalam hubungan secara umum dan juga kepuasan seksual. Perbedaan dalam suatu hubungan intim justru dapat membuat pasangan melakukan komunikasi yang terbuka mengenai isu seksual, kebutuhan dan fantasi tanpa harus merasa terbebani oleh kecemasan, sesuai dengan hipotesa yang menyebutkan bahwa perbedaan tajam dapat meningkatkan kemampuan untuk berkomunikasi mengenai isu-isu yang dirasakan sulit (misalnya mengenai seksualitas) sehingga keadaan ini dapat diterjemahkan sebagai suatu keadaan yang potensial secara seksual bagi pasangan untuk dapat meningkatkan kemampuan bertoleransi dalam hal keintiman. (MacNeil \& Byers, 2009; Montesi et al., 2013; Theiss, 2011; Timm \& Keiley, 2011)

Tujuan penelitian ini yaitu untuk mengetahui pengaruh kombinasi LODP dan komunikasi seksual terhadap hubungan seksual ibu pascasalin, sehingga diharapkan dapat menjadi metode alternatif dalam meningkatkan kualitas hubungan seksual, terutama bagi ibu pascasalin.

\section{METODE}

Desain penelitian menggunakan metode campuran (mixed method) dengan strategi concurrent embedded. Teknik consecutive sampling dipakai untuk memilih responden sejumlah 20 orang pada kelompok intervensi dan 20 orang pada kelompok kontrol. Penelitian dilakukan di wilayah Kecamatan Sukajadi Kota Bandung dengan sampel ibu pascasalin yang sesuai dengan kriteria inklusi yaitu: 1) berada dalam masa 2-3 bulan pascasalin; 2) tinggal satu rumah dengan pasangan. Adapun kriteria eksklusi yaitu jika ibu memiliki riwayat penyulit saat masa nifas, sedangkan kriteria drop out yaitu: 1) responden tidak melakukan LODP sesuai dengan instruksi; 2) salah satu pasangan pindah ke luar kota; 3) responden memutuskan mundur dari penelitian; dan 4) responden tidak dapat dihubungi. Dalam perjalanannya 1 orang responden kelompok kontrol masuk ke dalam kriteria drop out karena mengundurkan diri.

Pada tahap kuantitatif, desain yang digunakan adalah eksperimen bentuk semu pre-posttest control group design menggunakan kuesioner Female Sexual Function Index (FSFI) untuk mengetahui pengaruh LODP terhadap hubungan seksual. Pada tahap kualitatif, pendekatan fenomenologi dipakai untuk menggali perasaan responden mengenai kepuasan seksual setelah mendapatkan perlakuan. Panduan wawancara semi-terstruktur digunakan untuk membantu peneliti dalam memperoleh data. Selain pada responden, peneliti juga melakukan wawancara pada 3 orang suami responden di kedua kelompok, mengenai apa yang dirasakan oleh pasangan setelah mendapatkan perlakuan. Eksplorasi ini dilakukan untuk mendapatkan data mengenai pengaruh komunikasi seksual terhadap hubungan seksual, untuk mengeksplorasi lebih dalam mengenai pengaruh LODP dan untuk memperkaya deskripsi, terutama pada aspek penelitian kuantitatif yang tidak dapat dihitung (contoh: perasaan, keinginan, pemikiran).

Selama 6 minggu, responden pada kedua kelompok diminta melakukan LODP dengan ketentuan sebagai berikut:

1) 8 hari pertama, dilakukan selama 2 detik, frekuensi 10 kali per hari

2) 17 hari selanjutnya dilakukan selama 5 detik, frekuensi 5 kali per hari

3) 17 hari terakhir dilakukan selama 10 detik, frekuensi 5 kali per hari

Untuk kelompok intervensi, selain melakukan LODP, responden juga diminta untuk melakukan komunikasi seksual dengan pasangan setelah diberikan pendidikan kesehatan dan dibekali handout mengenai hal tersebut. Pengambilan data dilakukan 4 kali, yaitu pretest, dan posttest sebanyak 3 kali dengan jarak waktu 14 hari untuk setiap pengambilan data. Analisis data menggunakan uji Fisher, Shapiro-Wilk, dan Friedman. 


\section{H A S I L}

\section{Hasil Analisis Kuantitatif \\ Karakteristik Responden}

Usia responden pada kelompok intervensi dan kontrol sebagian besar berada dalam rentang 20-35 tahun, sedangkan sebagian besar responden menyusui dan keseluruhan responden merupakan akseptor KB (100\%).

Tabel Karakteristik Responden

\begin{tabular}{|c|c|c|c|}
\hline Karakteristik & $\begin{array}{c}\text { Intervensi } \\
(\mathbf{n}=\mathbf{2 0})\end{array}$ & $\begin{array}{c}\text { Kontrol } \\
(n=19)\end{array}$ & Nilai p* \\
\hline & \multirow[t]{3}{*}{0,231} \\
\hline $\begin{array}{l}<35 \\
\text { tahun }\end{array}$ & $17(85 \%)$ & $19(100 \%)$ & \\
\hline $\begin{array}{l}>35 \\
\text { tahun }\end{array}$ & $3(15 \%)$ & $0(0 \%)$ & \\
\hline $\begin{array}{l}\text { 2. Status } \\
\text { menyusui } \\
\text { Ya }\end{array}$ & $18(90 \%)$ & $16(84,21 \%)$ & \multirow[t]{2}{*}{0,661} \\
\hline Tidak & $2(10 \%)$ & $3(15,78 \%)$ & \\
\hline \multirow{3}{*}{$\begin{array}{ll}\text { 3. } & \text { Status } \\
\text { KB } \\
\text { Ya } \\
\text { Tidak }\end{array}$} & & & \multirow[t]{3}{*}{1,000} \\
\hline & $20(100 \%)$ & $19(100 \%)$ & \\
\hline & $0(0 \%)$ & $0(0 \%)$ & \\
\hline
\end{tabular}

Ket: * Menggunakan Fisher's exact test

\section{Perbandingan Pengaruh Latihan Otot Dasar Panggul Terhadap Hubungan Seksual Ibu Pascasalin \\ Dimensi Hasrat Seksual}

Kedua kelompok mengalami peningkatan skor secara signifikan $(\mathrm{p}<0.05)$ pada tiga kali periode pengambilan data. Melihat kenaikan skor tersebut, menandakan bahwa kedua kelompok mengalami peningkatan hasrat seksual setelah melakukan LODP.

\section{Dimensi Gairah Seksual, lubrikasi, dan orgasme}

Pada kelompok intervensi terjadi penurunan skor saat posttest 1 dan kenaikan saat posttest 2 dan 3 . Hal ini menandakan adanya penurunan gairah seksual, lubrikasi dan orgasme saat posttest 1 dan kembali meningkat saat posttest 2 dan $3(\mathrm{p}<0.05)$. Sementara di kelompok kontrol, responden mengalami peningkatan pada 3 kali periode pengambilan data $(\mathrm{p}<0.05)$.

\section{Dimensi Kepuasan Seksual}

Terjadi peningkatan skor yang signifikan saat 3 kali periode waktu pengambilan data pada kelompok kontrol $(\mathrm{p}<0.05)$. Sementara di kelompok intervensi, meskipun signifikan $(\mathrm{p}<0.05)$, namun tidak terjadi peningkatan ataupun penurunan skor saat pretest dan posttest 1 . Hal ini menandakan bahwa pada kelompok kontrol, responden mengalami peningkatan kepuasan seksual pada 3 kali periode pengambilan data. Sementara pada kelompok intervensi, responden merasakan kepuasan seksual yang sama saat pretest dan posttest 1 dan meningkat saat posttest 2 dan 3.

\section{Dimensi Nyeri}

Pada dimensi nyeri, jika terjadi kenaikan skor maka hal tersebut menandakan adanya penurunan rasa nyeri yang dialami responden saat berhubungan seksual, demikian pula sebaliknya. Peningkatan skor yang signifikan saat 3 kali periode waktu pengambilan data hanya terjadi di kelompok kontrol $(\mathrm{p}<0.05)$. Sementara di kelompok intervensi, meskipun signifikan $(\mathrm{p}<0.05)$, namun terjadi penurunan skor saat posttest 1, meningkat saat posttest 2 dan 3 . Hal ini menandakan bahwa pada kelompok kontrol responden mengalami penurunan nyeri pada 3 kali periode pengambilan data. Sementara pada kelompok intervensi, responden merasakan adanya peningkatan nyeri saat posttest 1, meskipun perbedaannya tidak terlalu jauh dengan pretest. Penurunan nyeri baru dirasakan saat posttest 2 dan 3 . 


\section{Gambar Kurva perbandingan pengaruh latihan otot dasar panggul terhadap hubungan seksual ibu pascasalin}

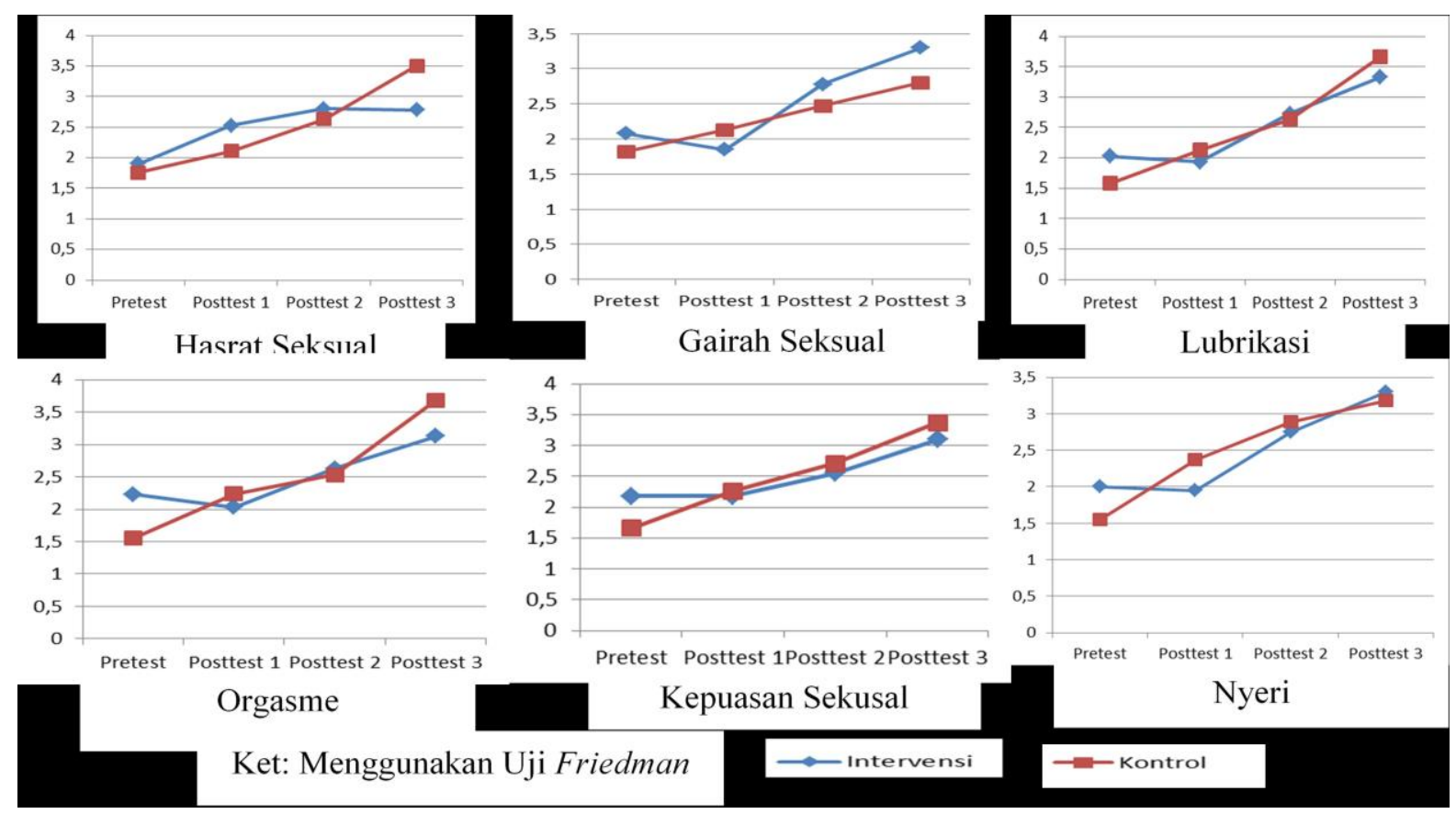

\section{Hasil Analisis Kualitatif \\ Hubungan Seksual Masa Pascasalin}

Setelah melewati 40 hari masa pascasalin keseluruhan informan merasakan adanya penurunan hasrat dan gairah seksual jika dibandingkan dengan sebelum bersalin karena berbagai penyebab, diantaranya yaitu mengalami kelelahan akibat aktivitas informan yang bertambah banyak dan pola tidur yang berubah karena sering terbangun di malam hari. Selain itu, ketidaknyamanan psikologis juga dialami oleh hampir seluruh responden saat melakukan hubungan seksual karena meraskan kekhawatiran (takut mengenai bekas luka jahitan perineum atau bekas luka operasi sectio caesaria, ataupun karena responden belum menjadi akseptor KB). Rasa khawatir bayinya akan terbangun atau risih karena merasa ada kehadiran bayi dalam ruangan yang sama saat responden melakukan hubungan seksual membuat konsentrasi responden terganggu saat melakukan hubungan seksual.
Ketidaknyamanan fisik karena merasa bentuk tubuhnya berubah dan dualisme fungsi payudaranya (sebagai alat seksual dan menyusui) juga memengaruhi penurunan hasrat dan gairah seksual responden. Semua ini memengaruhi terjadinya penurunan lubrikasi sehingga responden merasakan adanya nyeri saat berhubungan seksual. Dengan semua ketidaknyamanan yang dialami, responden mengalami penurunan kepuasan dalam hubungan seksual.

\section{Pengaruh LODP Terhadap Hubungan Seksual Ibu Pascasalin}

Saat minggu ke-3 dan 4, sebagian besar responden merasakan adanya perubahan di vagina hingga meningkatkan hasrat seksualnya:

"Ngga tau kenapa di vagina saya suka tiba-tiba kerasa ada linu aja gitu. Jadi kaya kenceng aja vaginanya, jadi kerasa pengen (berhubungan seksual) kalau udah begitu." (KI102: 08) 
Selain memengaruhi hasrat seksual, rasa kencang pada vagina juga mulai dirasakan memengaruhi keketatan vagina saat berhubungan seksual dan dirasakan menambah kenikmatan sehingga meningkatkan gairah seksual:

"Iiiihh, vagina saya jadi kenceng kayanya yah, soalnya kalau nyampur kerasa banget gesekannya. Malah terasa makin enak." (KI214: 05)

Rasa nyeri saat berhubungan seksual juga mengalami penurunan seiring dengan peningkatan lubrikasi:

"Rada (agak) meningkat gairahnya, ya itu udah mulai ngga sakit...kan kalau kemarin sayanya suka waswas trus jadi males karena ada sakit." (KI114: 04)

Pencapaian orgasme pun dirasakan lebih mudah oleh para responden:

"Lebih gampang orgasmenya, ngga susah nyampe, malahan mah sekarang kalau berhubungan seksual pasti orgasme. Ya lebih bergairah dong hehe lebih semangat, lebih puas" (KI212: 04)

Bahkan terdapat responden yang mencapai multiorgasme setelah melakukan LODP. Kepuasan seksual cenderung dirasakan meningkat terutama saat minggu ke-3 dan 4

"Lebih baik sih, Jadi ngga sakit terasanya, lebih enak, lebih nikmatin sayanya seneng hehehe." (KI101: 13)

Bukan hanya responden yang merasakan peningkatan kepuasan, tetapi juga pasangannya:

"Gimana ya... beda memang, kasarnya mah kerasa lebih rapet, udah mah dari abis lahiran memang kerasanya beda...lebih rapet, sekarang makin aja hehehe. Jadi lebih puas aja." (KISO2)

Ketidaknyamanan fisik dan psikologis memengaruhi lubrikasi sehingga kenikmatan karena meningkatnya keketatan vagina tidak selalu dirasakan oleh responden dan menyebabkan nyeri saat berhubungan seksual serta menurunkan kemampuan untuk orgasme dan kepuasan seksual. Hal ini terjadi karena berbagai hal, mulai dari terganggunya konsentrasi, kelelahan hingga kurangnya foreplay.

"Asa seuseut (kaya kering), jadi sakit perih. Biasanya mah banyak, makanya heran kenapa begitu. Iya mengganggu, jadi ngga nikmatin sayanya." (KI103: 04)

"Boro-boro kesitu (jangankan sampai kesitu-orgasme). Masih sama kaya sebelum senam ini. Saya masih suka ngerasain perih, jadi ngga enak. Pengen kaya dulu lagi, semangat gitu trus puas, sekarang mah ngga begitu." (KI113: 02)

Setelah ditelusuri lebih jauh, responden tersebut mengakui merasakan ketidaknyamanan fisik dan psikologis saat melakukan hubungan seksual.

"Mmmhh rada (agak) ada yang dipikirin sih, kan ini masih sekamar sama enin, nenek saya yang ngasuh dede, jadi takut bangun hehehe. Trus asa (perasaan) kurang pede yah sayanya, badan kan makin melar sejak ngelahirin kemarin, trus asa ngga puguh (tidak jelas perasaan) karena menyusui. Saya kan mudah terangsangnya kalau dipegang payudara, ari (kalau) sekarang payudara dipegang ngeluarin ASI...jadi asa teu puguh (merasa aneh)." (KI103: 04)

"Kayanya pemanasannya kurang, suami sayanya suka ngga sabaran (cemberut). Jadinya teh sayanya males nyampur (hubungan seksual), cuma jalanin kewajiban aja jadinya." (KI113: 02)

Terdapat responden di kedua kelompok yang mulai merasakan kenikmatan seksual tetapi belum mampu mencapai orgasme karena konsentrasi saat berhubungan seksual terganggu. 
"Belum bisa kalau orgasme sih. Suka ngga fokus sayanya hehe, takut anak saya bangun, dia gerak sedikit sayanya buyar...jadi asa kurang puguh (seperti tidak jelas perasaan)." (KI114: 03)

"Orgasme belum bisa. Takut anak sayanya bangun, kan jadi bentar-bentar nengok ke anak saya. Jadi ngga konsentrasi." (KK115: 04)

\section{Pengaruh Komunikasi Seksual Terhadap Hubungan Seksual Ibu Pascasalin}

Sebelum pelaksanaan perlakuan, beberapa responden dalam kelompok intervensi tidak segan untuk melakukan komunikasi dengan suami mengenai masalah seksual karena merasa hal tersebut penting bukan hanya untuk menunjang kepuasan seksual, tetapi juga untuk kepuasan diri dalam mengungkapkan emosi. Topik komunikasi bervariasi seputar hasrat seksual, kenikmatan seksual hingga ketidaknyamanan, dengan berbagai cara pengungkapan baik verbal, nonverbal ataupun kombinasi keduanya.

Kontras dengan keseluruhan informan pada kelompok kontrol dan sebagian responden kelompok intervensi, komunikasi seksual tidak dilakukan dengan baik karena berbagai alasan seperti malu, risih, gengsi, merasa hal tersebut tidak penting dan pasrah dengan keadaan yang ada. Beberapa responden melakukan komunikasi seksual jika hanya merasakan ketidaknyamanan saat melakukan hubungan seksual saja:

"Kalau sakit bilang. Kalau ngga sakit atau enak mah ngga bilang, sepertinya ngga perlu aja. Gimana yah, pengen ngomongin tapi malu." (KKA01:08)

Tidak dilakukannya komunikasi seksual dirasakan mengganjal oleh sebagian responden:
"Sering bikin kesel sih, cuman balik lagi...yaa udah deeeehh ngga diomongin. Males aja." (KIA07:03)

Saat mulai melakukan komunikasi seksual, pada umumnya responden merasa canggung karena belum terbiasa:

"Saya bilang langsung, saya bilang enak nyampurnya (tertawa malu). Awalnya mah malu, asa kumaha kitu nya (kaya gimana gitu yah) hahaha, tapi suami kayanya seneng dibilang begitu, ya jadi saya seneng juga." (KI204:23)

Dengan melakukan komunikasi seksual, para responden merasa dapat mengekspresikan dirinya sehingga timbul rasa santai, puas, bahkan hingga meningkatkan pengeluaran lendir vagina saat berhubungan seksual:

"Kan katanya jangan banyak pikiran biar ngga stres trus biar lendirnya banyak. Ketambah lagi udah plong sayanya, da udah diobrolin. Jadi udah lebih enak sekarang sih (berhubungan seksual)." (KI203:09)

Terdapat informan yang merasakan keintiman menjadi bertambah sejak melakukan LODP dan mengungkapkan kenikmatan seksual yang dirasakan meningkat. Hal ini ditunjang dengan respon pasangan positif terhadap informan yang semakin menambah kepuasan diri informan:

"Aduh, ngga usah ditanya deh soal puas mah, puas banget. Saya ngga bisa omongin lah, rumah tangga saya jadi harmonis lagi. Saya sama suami jadi pengennya deket-deketan aja, kaya penganten baru lagi, lebih greget hehehe. Ngerasa lebih deket, kaya dulu lagi (tersenyum). Alhamdulilah." (KI214: 10)

Sedangkan responden pada kontrol yang tidak melakukan komunikasi seksual merasakan seperti ada yang mengganjal perasaannya: 
"Iya suka pengen kadang mah diomongin kalau ngerasa enak juga, berbagi perasaan kan ngga harus yang ngga enak terus yah. Tapi malu ah, ngga kebayang harus gimana. Puas sih, tapi asa ada yang kurang aja, ngeganjel." (KK209: 04)

\section{DISKUSI}

\section{Dimensi Hasrat Seksual}

Pengaruh LODP terhadap keketatan vagina, yang berdampak pada peningkatan sensitivitas vagina saat berhubungan seksual sehingga meningkatkan kenikmatan dan kepuasan. Karena merasakan adanya peningkatan kenikmatan membuat responden ingin mengulang kembali hubungan seksual tersebut. Sejalan dengan model sirkular respon seksual wanita yang dikemukakan oleh Whipple dan Brash-McGreer, yang menyatakan bahwa refleksi pengalaman seksual yang menyenangkan memberikan pengaruh yang kuat terhadap hasrat seksual seorang wanita karena ingin kembali merasakan pengalaman yang dianggap memuaskan tersebut. (Damjanovic, Duisin, \& Barisic, 2013)

Levine dalam sebuah essay mendefinisikan hasrat seksual sebagai jumlah dari beberapa kekuatan yang dapat membuat seseorang mendekati ataupun menjauhi perilaku seksual. Menurutnya terdapat tiga kekuatan yang menjadikan seseorang memiliki hasrat seksual, yaitu (1) dorongan, merupakan komponen biologis mencakup anatomi dan fisiologi neuroendokrin; (2) motivasi, sebuah komponen psikologis yang dipengaruhi oleh keadaan mental seseorang (contoh: rasa senang atau kesedihan), keadaan interpersonal seseorang (contoh: hubungan antar sesama, perselisihan), dan konteks sosial (contoh: durasi hubungan, ketidaksetiaan); (3) keinginan, yaitu komponen kultural yang menggambarkan nilai-nilai, pemahaman dan aturan mengenai ekspresi seksual yang tertanam sejak kanak-kanak dan kemungkinan tergambar kembali sepanjang kehidupan. (Levine, 2003)

Meskipun kenikmatan seksual dirasakan meningkat karena sensitivitas vagina yang bertambah akibat pengaruh LODP tetapi beberapa faktor turut memengaruhi hasrat seksual seperti pengurangan lendir vagina karena merasa konsentrasinya terganggu akibat keberadaan orang lain dalam ruangan yang sama (pengasuh) saat berhubungan seksual dan foreplay yang dirasakan kurang sehingga responden tersebut merasakan adanya ketidaknyamanan ataupun nyeri saat berhubungan seksual dan menimbulkan perasaan enggan untuk mengulanginya sehingga malas untuk memulai hubungan seksual. Sesuai dengan konsep yang diutarakan oleh Levine, bahwa hasrat seksual melibatkan dorongan fisik dan psikologis yang memengaruhi motivasi seorang wanita untuk berhubungan seksual dan digabungkan dengan model respon seksual wanita yang diungkapkan oleh Whipple dan BrashMcGreer, bahwa hasrat seksual wanita merupakan refleksi dari pengalaman sebelumnya, maka dapat dipahami jika ketidaknyamanan ini menimbulkan penurunan hasrat seksual. (Damjanovic et al., 2013; Levine, 2003)

\section{Dimensi Gairah Seksual}

Peningkatan keketatan vagina memberikan pengaruh positif terhadap kenikmatan seksual sehingga responden merasakan semakin bergairah saat berhubungan seksual. Graber dalam Lowenstein menyatakan bahwa kekuatan otot dasar panggul diyakini memiliki kaitan dengan sensasi yang dirasakan oleh wanita selama proses hubungan seksual dan juga memengaruhi kekuatan "cengkraman" vagina yang dapat dirasakan oleh pasangannya. Jika disertai stimulasi seksual yang tidak terputus maka terjadi peningkatan gairah seksual yang akan terus meningkat hingga mencapai titik maksimal. Dalam beberapa studi ditemukan bahwa wanita dengan otot dasar 
panggul yang kuat memiliki perbedaan yang bermakna dalam dimensi gairah seksual dibandingkan dengan wanita yang memiliki otot dasar panggul lemah $(p<0,01)$ (Lowenstein, Gruenwald, Gartman, \& Vardi, 2010; Martinez, Ferreira, Castro, \& Gomide, 2014)

Citak et al menyatakan bahwa pada kelompok intervensi mengalami peningkatan gairah seksual yang signifikan setelah diberikan LODP dibandingkan dengan kelompok kontrol $(p<0,01)$. Semakin sering melakukan LODP, pengaruhnya semakin terasa oleh kedua kelompok. (Citak et al., 2010)

Selain peningkatan, pada analisa kualitatif terdapat responden yang merasakan adanya gangguan gairah seksual karena ketidaknyamanan psikologis. Selaras dengan Frijda dan Everaerd et al dalam Chivers yang menyebutkan bahwa gairah seksual merupakan gabungan dari komponenkomponen yang saling berinteraksi, termasuk didalamnya perubahan psikologis, ekspresi emosi dan perilaku motivasi. Gairah seksual juga dipengaruhi oleh hal-hal yang terjadi sebelumnya (stimulus seksual) dan pola ekspresi (psikologis, fisik dan perilaku) yang berfungsi untuk mengatur perilaku reproduksi seksual mendasar. Perlu diketahui bahwa gairah seksual bersifat subjektif dan juga merupakan sebuah penilaian terhadap berbagai unsur psikologis seperti kognisi, emosi dan persepsi yang terintegrasi serta dinamis. Hasil dari penilaian tersebut adalah respon gairah seksual fisiologis yang dapat bersifat umum ataupun spesifik. (Chivers, 2005)

Kurangnya stimulasi seksual saat sebelum hubungan seksual dilakukan juga dikaitkan dengan menurunnya gairah seksual wanita. Seperti beberapa studi yang tercantum dalam Kuile et al yang menyatakan bahwa wanita yang dinyatakan sehat secara fisik dan memiliki genital yang mampu melakukan respon seksual namun mengalami gangguan gairah seksual, diduga berkaitan dengan kurangnya stimulasi seksual atau tidak mengalami stimulasi seksual sama sekali. (ter Kuile, Both, \& van Lankveld, 2010)

\section{Dimensi Lubrikasi}

Lendir vagina saat berhubungan seksual berfungsi sebagai lubrikasi untuk mengurangi nyeri akibat gesekan penis terhadap vagina. Saat terjadi stimulasi seksual, impuls sensorik menjalar sepanjang saraf sakrum melalui saraf pudendal dan mengakibatkan darah mengalir lebih banyak ke organ genital. Dikendalikan oleh saraf eferen, aliran ini di distribusikan ke vagina, uterus dan otot dasar panggul. Sebagai konsekuensi dari meningkatnya sirkulasi darah, vulva dan vagina menjadi membengkak dan kelenjarkelenjar yang saling berhubungan pada saluran reproduksi meningkatkan sekresi seiring dengan berlangsungnya gairah seksual. (Lowenstein et al., 2010)

Oleh sebab itu, dimensi lubrikasi akan meningkat selaras dengan dimensi gairah seksual dan begitu pula sebaliknya, lubrikasi akan berkurang jika gairah seksual menurun. Kedua dimensi ini memegang peranan penting dalam kenikmatan seksual wanita, karena seperti tergambar dalam hasil penelitian ini bahwa meskipun LODP yang dilakukan memberikan pengaruh positif terhadap keketatan vagina, tetapi tidak semua responden merasakan kenikmatan seksual. Terdapat penurunan dimensi lubrikasi yang dirasakan mengganggu oleh responden karena kelelahan dan faktor psikologis yang mengganggu gairah seksual responden. Keadaan ini memicu terjadinya ketidaknyamanan personal selama melakukan hubungan seksual, bahkan setelahnya.

Terganggunya gairah seksual dapat menyebabkan penurunan lubrikasi dan menyebabkan ketidaknyamanan psikologis seperti studi yang dilakukan oleh Bancroft et al dalam Brotto et al saat melakukan pendekatan kualitatif untuk mengetahui distres personal VS interpersonal 
hubungannya dengan masalah lubrikasi, sebanyak $32 \%$ responden mengeluhkan penurunan lubrikasi yang seringkali menjadi pemicu distress, kecuali pada wanta postmenopausal. (Brotto, Bitzer, Laan, Leiblum, \& Luria, 2010)

\section{Dimensi Orgasme}

Beberapa studi menjelaskan bahwa kontraksi otot dasar panggul, khususnya otot pubokoksigis dan iliokoksigeus serta membran perineum dipercaya berperan dalam fungsi dan respon seksual wanita, termasuk ritmik kontraksi involunter dan modulasi dalam reseptor serta respon motorik selama orgasme. Beberapa studi menunjukkan peningkatan fungsi seksual wanita, termasuk dimensi orgasme, pada wanita dengan otot dasar panggul yang kuat. (Citak et al., 2010; Lowenstein et al., 2010)

Namun terdapat faktor yang memengaruhi sulit atau tidaknya responden dalam mencapai orgasme, seperti terganggunya konsentrasi sehingga terjadi penurunan gairah seksual seperti diungkapkan dalam Sun et al bahwa wanita dengan gangguan gairah seksual dapat mengalami kesulitan dalam orgasme. (Sun, Huang, Yang, Cao, \& Zhou, 2014) Seperti telah dijelaskan pada dimensi gairah seksual, bahwa saat mencapai titik gairah seksual yang maksimal maka wanita tersebut akan mengalami rangkaian fisiologis orgasme. Namun harus juga diingat gairah seksual merupakan gabungan dari komponen-komponen yang saling berinteraksi, termasuk didalamnya perubahan psikologis, ekspresi emosi dan perilaku motivasi. Sehingga perubahan negatif kondisi psikologis seorang wanita akan turut memengaruhi mudah atau tidaknya pencapaian orgasme dari wanita tersebut. (Chivers, 2005)

\section{Dimensi Kepuasan Seksual}

Beberapa studi yang menemukan adanya korelasi antara kekuatan otot dasar panggul dan peningkatan kepuasan seksual $(p<0,05)$. Studi tersebut menjelaskan bahwa wanita dengan otot dasar panggul yang kuat cenderung mengalami peningkatan kenikmatan seksual sehingga memengaruhi dimensi-dimensi hubungan seksual, termasuk kepuasan seksual yang merupakan pengaruh dari meningkatnya keketatan dan sensitivitas vagina saat berhubungan seksual. (Citak et al., 2010; El-Begway, Elshamy, \& Hanfy, 2010; Martinez et al., 2014)

Peningkatan kenikmatan seksual juga dirasakan oleh pasangan responden yang berdampak positif pada kepuasan pasangan. Tidak dapat dipungkiri bahwa keadaan ini menambah keintiman pasangan dan memberikan tambahan kepuasan seksual bagi responden. Searah dengan penelitian yang dilakukan Pascoal dan Narciso, bahwa konsep utama untuk mendefinisikan kepuasan seksual adalah kesejahteraan seksual secara personal dan proses diadik. Hubungan antara keduanya juga sesuai dengan teori sistem keluarga karena membuktikan bahwa kepuasan seksual merupakan konsep dua-dimensi dimana terdapat keterkaitan antara dimensi personal dan relasional. (Pascoal, Narciso, \& Pereira, 2014)

\section{Dimensi Nyeri}

Meskipun merasakan peningkatan keketatan vagina, namun tidak semua responden dapat menikmati proses hubungan seksual karena terjadi penurunan lubrikasi yang menyebabkan rasa nyeri menjadi meningkat. Pada studi yang dilakukan oleh El-Begway et al ditemukan bahwa setelah melakukan LODP, responden tidak mengalami penurunan rasa nyeri saat melakukan hubungan seksual (p<0.05). (El-Begway et al., 2010) Menurut Frank et al lubrikasi yang tidak adekuat selama hubungan seksual dapat menyebabkan gesekan antara penis dan vagina sehingga menyebabkan trauma kecil pada jaringan epitelium vulva dan vagina. Kurangnya lubrikasi ini dapat terjadi karena penurunan gairah seksual atau kekeringan vagina kronis. (Seehusen et al., 2014) 


\section{Pengaruh Komunikasi Seksual Terhadap Hubungan Seksual Ibu Pascasalin}

Komunikasi seksual yang dilakukan oleh kelompok intervensi memberikan pengaruh positif tambahan terhadap hubungan seksual responden, sehubungan dengan adanya peningkatan kepuasan diri karena terfasilitasinya aktualisasi diri dan pengungkapan emosi. Searah dengan MacNeil dan Byers dalam Montesi et al yang menyatakan bahwa komunikasi seksual merupakan elemen menuju "perkembangan dan pemeliharaan sebuah hubungan seksual yang memuaskan." Responden juga merasakan meningkatnya keintiman, sesuai dengan konsep membangun keintiman melalui komunikasi yang terbuka dan jujur mengenai masalah seksual. Dalam beberapa studi ditemukan hubungan antara kemampuan melakukan komunikasi seksual dengan baik dan kepuasan seksual serta kepuasan pernikahan $(\mathrm{p}<0,001)$. Responden pada studinya yang mengaku merasa kecewa dengan komunikasi seksual antara dirinya dan pasangan juga dilaporkan merasakan kekecewaan dalam hubungan seksual secara keseluruhan. Studi ini menyimpulkan bahwa pengungkapan diri (sexual self-disclosure) merupakan bagian yang tidak terpisahkan dalam komunikasi seksual dan bermanfaat untuk meningkatkan kepuasan diri dan dalam suatu hubungan, kepuasan seksual serta keintiman pasangan yang juga memiliki hubungan positif terhadap peningkatan dan pemenuhan kebahagiaan. (Khoury \& Findlay, 2014; Montesi et al., 2013; Timm \& Keiley, 2011)

Komunikasi yang terbuka dengan pasangan mengenai seksual dapat menjadi jembatan bagi kepuasan, bukan hanya kepuasan dalam hal seksual itu sendiri, tetapi juga menuju kepuasan suatu hubungan secara keseluruhan. Hal ini terjadi karena mungkin dengan membicarakan masalah seksual dapat memfasilitasi pertukaran kepuasan seksual sehingga masing-masing individu dapat mengetahui peningkatan kepuasan pasangannya dalam aspek seksual yang merupakan bagian dari suatu hubungan. Pasangan yang melakukan komunikasi seksual berarti secara langsung meningkatkan kepuasan seksualnya sekaligus kepuasan mereka akan hubungan dalam satu konteks yang utuh. (Montesi, Fauber, Gordon, \& Heimberg, 2010)

Respon pasangan juga memegang peranan penting dalam keberhasilan komunikasi seksual. Jika respon pasangan positif maka diharapkan dapat meningkatkan keintiman, namun jika pasangan tidak merespon kembali atau respon pasangan negatif maka dikhawatirkan akan menimbulkan "jarak" secara emosional antar pasangan sehingga mengakibatkan perasaan malas pada diri responden untuk kembali melakukan komunikasi seksual. Jika hal ini terjadi, keintiman pasangan kemungkinan akan berkurang seperti diungkapkan oleh Davidson \& Darling dalam studi yang dilakukan oleh Theiss, bahwa karakteristik-karakteristik negatif seperti konflik yang tidak terselesaikan, terdapat jarak emosional dan perasaan tidak dicintai diprediksi mengurangi kepuasan seksual, dimana keintiman menjadi salah satu elemennya. (Theiss, 2011)

Peningkatan kepuasan seksual yang dirasakan lebih oleh responden kelompok intervensi karena melakukan komunikasi seksual sesuai dengan hasil studi Timm et al yang menemukan bahwa keintiman pada orang dewasa secara signifikan berhubungan dengan salah satunya adalah elemen komunikasi seksual. Hasil studi ini mendukung penemuan pada beberapa literatur sebelumnya yang menjelaskan bahwa hubungan dengan tingkat keintiman yang baik akan menjadi dasar bagi sebuah kepuasan dalam hubungan, serta dibutuhkan salah satunya adalah komunikasi seksual untuk membangun keintiman tersebut. (Timm \& Keiley, 2011) 


\section{PENUTUP}

Latihan Otot Dasar Panggul terbukti dapat meningkatkan kualitas hubungan seksual ibu pascasalin melalui mekanisme peningkatan keketatan vagina sebagai hasil dari latihan penguatan dasar panggul. Namun, keketatan vagina tidak selalu menjadi hal yang menyenangkan bagi wanita saat melakukan hubungan seksual karena terdapat unsur psikologis yang memengaruhi dimensi-dimensi seksualitas seperti hasrat seksual, gairah seksual, lubrikasi, orgasme, kepuasan dan nyeri saat berhubungan seksual. Salah satu cara untuk menjembatani ketidaknyamanan wanita saat berhubungan seksual yaitu dengan menerapkan komunikasi seksual bersama pasangan yang diharapkan dapat menjadi ajang diskusi dalam rangka memenuhi salah satu elemen dalam kebutuhan fisiologis tersebut. 


\section{DAFTAR PUSTAKA}

Acele, E. Ö., \& Karaçam, Z. (2012). Sexual problems in women during the first postpartum year and related conditions. Journal of Clinical Nursing, 21(7-8), 929-937. https://doi.org/10.1111/j.13652702.2011.03882.x

Brækken, I. H., Majida, M., Ellström Engh, M., \& Bø, K. (2015). Can Pelvic Floor Muscle Training Improve Sexual Function in Women with Pelvic Organ Prolapse? A Randomized Controlled Trial. Journal of Sexual Medicine, 12(2), 470-480. https://doi.org/10.1111/jsm.12746

Brotto, L. A., Bitzer, J., Laan, E., Leiblum, S., \& Luria, M. (2010). Women's sexual desire and arousal disorders. Journal of Sexual Medicine, 7(1 PART 2), 586-614. https://doi.org/10.1111/j.17436109.2009.01630.x

Chivers, M. L. (2005). A brief review and discussion of sex differences in the specificity of sexual arousal. Sexual and Relationship Therapy, 20(4), 377-390.

https://doi.org/10.1080/14681990500 238802

Citak, N., Cam, C., Arslan, H., Karateke, A., Tug, N., Ayaz, R., \& Celik, C. (2010). Postpartum sexual function of women and the effects of early pelvic floor muscle exercises. Acta Obstetricia et Gynecologica Scandinavica, 89(6), 817-822. https://doi.org/10.3109/00016341003 801623

Damjanovic, A., Duisin, D., \& Barisic, J. (2013). The evolution of the female sexual response concept: Treatment implications. Srpski Arhiv Za Celokupno Lekarstvo, 141(3-4), 268274.

https://doi.org/10.2298/SARH130426 $8 \mathrm{D}$

El-Begway, A. F., Elshamy, F. F., \&
Hanfy, H. M. (2010). The Effect of Pelvic Floor Exercise on Sexual Function after Vaginal Delivery. Med. J. Cairo Univ, 78(2), 27-31. Retrieved from www.medicaljournalofcairouniversity .com

Galuh Suryondari, C., \& Yuni Indah Nurmala, E. (2016). Efektifitas Kegel Exercise untuk Pencegahan Postpartum Female Sexual Dysfunction dalam Upaya Peningkatan Kualitas Keluarga, 2532.

Johnson, C. E. (2011). Sexual health during pregnancy and the postpartum (CME). Journal of Sexual Medicine, $8(5)$, 1267-1284. https://doi.org/10.1111/j.17436109.2011.02223.x

Khoury, C. B., \& Findlay, B. M. (2014). What Makes for Good Sex? The Associations Among Attachment Style, Inhibited Communication and Sexual Satisfaction. Journal of Relationships Research, 5(2014), e7. https://doi.org/10.1017/jrr.2014.7

Lamont, J., Bajzak, K., Bouchard, C., Burnett, M., Byers, S., Cohen, T., ... Senikas, V. (2012). Female Sexual Health Consensus Clinical Guidelines. Journal of Obstetrics and Gynaecology Canada, 34(8), S1-S4. https://doi.org/10.1016/S17012163(16)35353-1

Levine, S. B. (2003). The Nature of Sexual Desire: A Clinician's Perspective 1. Archives of Sexual Behavior, 32(3), 279-285.

https://doi.org/10.1023/A:102342181 9465

Lowenstein, L., Gruenwald, I., Gartman, I., \& Vardi, Y. (2010). Can stronger pelvic muscle floor improve sexual function? International Urogynecology Journal, 21(5), 553556. https://doi.org/10.1007/s00192009-1077-5

MacNeil, S., \& Byers, E. S. (2009). Role of sexual self-disclosure in the sexual 
satisfaction of long-term heterosexual couples. Journal of Sex Research, 46(1), 3-14. https://doi.org/10.1080/00224490802 398399

Martinez, C. S., Ferreira, F. V., Castro, A. A. M., \& Gomide, L. B. (2014). Women with greater pelvic floor muscle strength have better sexual function. Acta Obstetricia et Gynecologica Scandinavica, 93(5), 497-502.

https://doi.org/10.1111/aogs.12379

Montesi, J. L., Conner, B. T., Gordon, E. A., Fauber, R. L., Kim, K. H., \& Heimberg, R. G. (2013). On the relationship among social anxiety, intimacy, sexual communication, and sexual satisfaction in young couples. Archives of Sexual Behavior, 42(1), 81-91.

https://doi.org/10.1007/s10508-0129929-3

Montesi, J. L., Fauber, R. L., Gordon, E. A., \& Heimberg, R. G. (2010). The specific importance of communicating about sex to couples, sexual and overall relationship satisfaction, 28(5), 591-609. https://doi.org/10.1177/02654075103 86833

Pascoal, P. M., Narciso, I. D. S. B., \& Pereira, N. M. (2014). What is sexual satisfaction? Thematic analysis of lay people's definitions. Journal of Sex Research, 51(1), 22-30. https://doi.org/10.1080/00224499.201 3.815149

Seehusen, D. A., Baird, D. C., \& Bode, D. V. (2014). Dyspareunia in women. American Family Physician, 90(7), 465-470.

https://doi.org/10.1016/j.nurpra.2008. 04.009

Serati, M., Salvatore, S., Siesto, G., Cattoni, E., Zanirato, M., Khullar, V., ... Bolis, P. (2010). Female Sexual
Function during Pregnancy and after Childbirth. The Journal of Sexual Medicine, 7(8), 2782-2790. https://doi.org/10.1111/j.17436109.2010.01893.x

Sun, Q., Huang, J., Yang, D. L., Cao, X. N., \& Zhou, W. L. (2014). Activation of $\beta$-adrenergic receptors during sexual arousal facilitates vaginal lubrication by regulating vaginal epithelial Cl-secretion. Journal of Sexual Medicine, 11(8), 1936-1948. https://doi.org/10.1111/jsm.12583

ter Kuile, M. M., Both, S., \& van Lankveld, J. J. D. M. (2010). Cognitive behavioral therapy for sexual dysfunctions in women. Psychiatric Clinics of North America, 33(3), 595-610. https://doi.org/10.1016/j.psc.2010.04. 010

Theiss, J. A. (2011). Modeling dyadic effects in the associations between relational uncertainty, sexual communication, and sexual satisfaction for husbands and wives. Communication Research, 38(4), 565-584.

https://doi.org/10.1177/00936502114 02186

Thielke, S., Harniss, M., Thompson, H., Patel, S., Demiris, G., \& Johnson, K. (2012). Maslow's Hierarchy of Human Needs and the Adoption of Health-Related Technologies for Older Adults. Ageing International, $37(4)$, 470-488. https://doi.org/10.1007/s12126-0119121-4

Timm, T. M., \& Keiley, M. K. (2011). The effects of differentiation of self, adult attachment, and sexual communication on sexual and marital satisfaction: A path analysis. Journal of Sex and Marital Therapy, 37(3), 206-223.

https://doi.org/10.1080/0092623X.20 11.564513

Zakšek, T. Š . (2015). Sexual Activity during Pregnancy in Childbirth and 
after Childbirth. 